\title{
Manuscript of Kitab Sifat Dua Puluh: The Portrait of Moderate Islamic Theological Doctrines from Interior Borneo.
}

\author{
Faizal Amin', Moh. Nor Ichwan² \\ ${ }^{1}$ Institut Agama Islam Negeri Pontianak, Indonesia; \\ 2Universitas Islam Negeri Walisongo, Semarang - Indonesia \\ e-mail: 1faizalamin@hotmail.com; 2nor_ichwan@walisongo.ac.id
}

\begin{abstract}
The construction of religious moderation is not only derived from the context of practices but also the texts of its theological doctrines. Manuscripts of Kitab Sifat Dua Puluh from West Kalimantan is a primary source to study the basis of Islamic religious moderation in Interior Borneo. The texts of the manuscript are no longer presented as a copy of al-Sanūsìs Umm al-Barāhīn but it has become a corpus that accommodates local genius dan tradition. This article aims to examine the moderation of Islamic theological doctrine derived from the texts of the manuscript of twenty attributes of God. The texts of a manuscript considered as one of the sustainable best practices of South-East Asian localisations of Islam because it was one of the basic references for local Dayak Muslim community learning Islam in interior Boneo. This article is based on the results of philological studies on the manuscript collection written by Abang Ahmad Tahir (1860-1945) in Kapuas Hulu, West Kalimantan, Indonesia. The moderate Islamic theological doctrine in Abang Ahmad Tahir's manuscript collection can be seen through three indicators namely the simplicity of the narrative articulation and arguments of the attributes of God, the synthesis of Islamic theological doctrine with Sufi doctrine, and the content of the text that gives no room for hate speech against local tradition and different systems of belief of the indigenous offspring of West Kalimantan.
\end{abstract}

Keywords: Islamic theology; local genius; representation; Sufism; synthesis.

\section{A. Introduction}

The popularity of Kitab Sifat Dua Puluh (The Book of Twenty Attributes of God) as Islamic subject written Malay texts not only shows local genius adaptation but also moderate Islamic doctrine. Even though the texts of twenty attributes of God originated from the exposition of Abū Abdullāh Muhammad ibn Yūsuf al-Sanūsī (d. 1490) in his famous work Umm al-Barāhīn (Mothers of 
All Proofs), but the copies of its text appear in many different composition. ${ }^{1}$ The differences of Kitab Sifat Dua Puluh compositions are expressed not only in both lengthy and abbreviated forms but also written in both prose and verse (syair). The texts have also been found in many editions not only in print but also in manuscript copies that mostly date from the $19^{\text {th }}$ century. Today, the printed edition text is still commonly read, taught, and sold in traditional Islamic book stores. As an Islamic theological doctrine, the text of Kitab Sifat Dua Puluh proposes a simple moderate view of Sunnism and does not attack some local religious beliefs and rituals considered as opposed to Islamic monotheism.

The studies of theological texts of Borneo ulama since the eighteenth century up to the early twenty-first century have had some tendencies both in edition and contents.2 The theological texts produced and transmitted by the Borneo ulama from the eighteenth to the nineteenth century were written in Jawi. By the twentieth century, the theological texts also produced in the Indonesian language, but the use and production of Arabic and Jawi texts continued. Sanusi's conception of Sunni theology has become dominant content among Muslims in Kalimantan. However, since the 1920s, this dominant theology has been challenged by Salafism introduced by the reformist Muslim group, the Muhammadiyah. By the 1990s, some of the ulama had proposed the theology of God's Beautiful Names as an alternative to the Sanusi's conception. All of these theological conceptions, however, seem to pay too little attention to the challenges of the increasing religious plurality of Kalimantan society.

This article based on the argument that the texts of Sanusi's conception of Sunni theology in the manuscript of Kitab Sifat Dua Puluh not only has a distinctive narration but also a basic synthesis with Sufism. The centuries-long processes of 'Islamisation' in the Indonesian archipelago presents a balance to prevalent understandings of the extent of localisation. There are rich traditions

${ }^{1}$ Annabel Teh Gallop, “The Twenty Attributes of God in Malay: Sifat Dua Puluh,” The British Library: Asian and African studies blog, 2015, https://blogs.bl.uk/asian-andafrican/2015/12/the-twenty-attributes-of-god-in-malay-sifat-dua-puluh.html; Annabel Teh Gallop et al., "A Jawi Source Book for The Study of Malay Paleography and Orthography," Indonesia and the Malay World 43, no. 125 (2015): 13-171, https://doi.org/10.1080/13639811.2015.1008253.

2 Mujiburrahman, "Islamic Theological Texts and Contexts in Banjarese Society: An Overview of the Existing Studies," Southeast Asian Studies 3, no. 3 (2014): 611-41. 
of Islamic religious thought and practice through-out South-East Asia, comprising a diverse array of local expressions. Mainland Muslim communities have complex histories in which the mutual interaction of Islamicate, Indic and indigenous cultural forms have been dynamically negotiated. ${ }^{3}$ The dynamics of working out such redefinitions of religion and society has been described by Marshall Hodgson as the 'naturalization of Islam' in South East Asia. ${ }^{4}$ One important factor in this was the role played by an evolving canon of Arabic texts that both linked local scholars to current discussions in the broader Muslim world and provided the basis for emerging bodies of vernacular Islamic scholarship. ${ }^{5}$

This article aims to show Islamic theological doctrine derived from the manuscript texts of Kitab Sifat Dua Puluh written by Abang Ahmad Tahir (18601945) in Kapuas Hulu, West Kalimantan, Indonesia. The texts of a manuscript of Kitab Sifat Dua Puluh are considered as one of the sustainable best practices of South-East Asian localisations of Islam because it was one of the basic references for local Dayak Muslim community learning Islam in interior Boneo. This article is based on the results of philological studies of Kitab Sifat Dua Puluh which are contextualized in language representation with a constructionist approach. Language representation in the manuscript of Kitab Sifat Dua Puluh refers to the forms of vocabulary and expressions that contain the shared meaning of shared understanding that connects elements and characteristics of Islamic theological discourse of the indigenous people of West Kalimantan.

${ }^{3}$ R Michael Feener, "South-East Asian Localisations of Islam and Participation within a Global Umma, c. 1500-1800," in The New Cambridge History of Islam, ed. Morgan. David 0 and Anthony Reid, Online (Cambridge: Cambridge University Press, 2015), 470-71, https://doi.org/http://dx.doi.org/10.1017/CHOL9780521850315.

${ }^{4}$ Marshall G S Hodgson, The Venture of Islam (Chicago: University of Chicago Press, 1974), 548.

5 By at least the sixteenth century, Islamic religious texts in Arabic were being translated and adapted into South-East Asian languages, early examples of which in Malay appear to date from the late sixteenth century in the form of vernacular adaptations of the creed of al-Nasafi - (d. 1142), and the 'Mantle' poem (Burda) in praise of the Prophet by alBus.1 ${ }^{-}{ }^{-}$(d. 1296). The oldest surviving examples of analogous developments in Javanese date from a few decades earlier in the sixteenth century and draw considerably upon the works of al-Ghaza-ll" (d. 1111). Feener, "South-East Asian Localisations of Islam and Participation within a Global Umma, c. 1500-1800," 473. 


\section{B. Simple Narrative of the Text}

This discussion of the doctrine of the twenty attributes of Allah is described by Abang Ahmad Tahir in three manuscripts, namely MS AAT 01, MS AAT 02, and MS AAT 05. MS AAT 01 which is entitled "This is the Twenty Attributes that includes Qawaid Fifty to the sentence Lā ilāha illa Allāhu Muhammad Rasūlullāh." The title text is written on a piece of paper attached to the cover of the manuscript. While on the cover of MS AAT 05, the title reads "This is the Book of Guidance for the Pillars of Islam and the Pillars of Prayer and Fasting and Zakat." Nevertheless, MS AAT 05 and MS AAT 01 have the same narrative text about the Twenty Attributes. The MS AAT 05 text on page / 18r / - / 20r / contains the same narration as the MS AAT 01 text on page / $1 \mathrm{r} /-/ 2 \mathrm{r} /$. The diction and sentence structure are partly the same so the results of the comparison of the two texts can actually complement the corrupt parts. Nevertheless, the similarity of the narrative articulation of the text of the two manuscripts of Abang Ahmad Tahir's collection only ranges up to two pages, with the final page containing the illustration table. When compared between the two texts, the MS AAT 05 narration is better in terms of the text pad and better completeness of the text content. One part of the text that is repeated is as follows:

.. Karena tersebut di dalam hadith daripada kitab Daqāiq al-Akhbar: ("Lā yuḥraqu aḥadun min al-kuffār 'alā șuratih bal tubaddalu șūratahu 'alā șūratah al-khinzīr'). Artinya tiada hangus seorang kafir itu atas rupa asal dan tetapi digantikan rupanya atas rupa babi. Adapun Allah taala menyuruh segala hambanya sembahyang mufakat dengan huruf nama "Ahmad" (أحمد). Berdiri betul itu seperti "alīf" (أحم). Adapun rukuk itu seperti "hă $\bar{a} "(ح)$. Adapun sujud itu seperti
... Because it is mentioned in the hadith rather than the book Daqãiq al-Akhbar: ("Lā yuhraqu ahadun min al-kuffār 'alā șuratih bal tubaddalu șūratahu 'alā șūratah al-khinzīr"). It means that the infidel is not burnt on the original appearance and but replaced on the appearance of a pig. Indeed Allah Almighty commands all his servants to pray in agreement with the letters of the name "Ahmad" (أحمد), standing right like "alif" (أ). As for the bow, it is like "hă $\bar{a} "(ح)$. As for prostration, it is like 


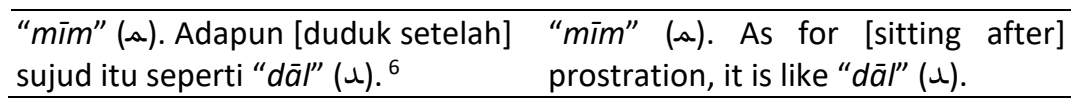

The phenomenon of the repetition of the narrative text written by Abang Ahmad Tahir, if examined with a textual research approach or research on the corpus of the book as textual research, then what Tahir did is unnecessary. According to Bauman, 7 the repetition of narrative text or parallelism in performance is usually combined with intonation, sound, sentence structure, and the content of meaning as the elements that build a conversation (speech). But instead, the phenomenon of repeating the narrative text is precisely the important thing that may be intentionally done by Tahir to provide reinforcement both to the narrative content and to the audience of readers. The repetition of the MSS AAT text narration about the twenty attributes shows that the theme as the text content is important so that it is repeated in such a way in different parts. The repetition of the narration is also intended to reinforce to the reader so that the concept of the twenty attributes as part of theological doctrine not only gets more attention but also its understanding is increasingly embedded in the heart of the reader. This understanding can be obtained if the phenomenon of MSS AAT text repetition is seen based on its social function and how it lives in the routines of its users, in their subconscious mind, either collectively or individually in the group of indigenous offspring of West Kalimantan.

The narrative text about the attributes of Allah in MS AAT $01 / 1 \mathrm{r} /-$ / $2 \mathrm{r}$ / and MS AAT 05 / 18r / - / 20r / begins by stating what is necessary to be of His attributes, and what is impossible to be of His attributes that must be known by the salik are twenty respectively. The narrative text in MS AAT 01 and MS AAT 05 reads "As for what is necessary to be of His attributes 0 Salik, that is twenty attributes of God that must be known by us as well as what is impossible to be of His attributes." The mention of the word 'salik' to greet the

${ }^{6}$ Abang Ahmad C N - M S A A T 01 Tahir, "Sifat Dua Puluh Semitau” (Putussibau, April 18, 1902), /2r/; Abang Ahmad C N - M S A A T 05 Tahir, "Kitab Risalah Perukunan Islam" (Putussibau, April 18, 1921), /18v/.

7 Charles J. Adams, "Forward," ed. Richard C. Martin (USA: The Arizona Board of Regents, 1985).

JURNAL THEOLOGIA — Volume 31, No. 2, Desember 2020 
audience in the narration of MS AAT 01 shows the classification of this book which is part of the domain of Sufism. This is different from the audience greetings in MS AAT 02 although both of them also contain texts about the concept of the attributes of Allah and His messengers. In comparison, MS AAT 01 states the obligation to know the attributes of Allah is described for "salik," while MS AAT 02 emphasizes such obligation for "those having reached puberty" by stating:

\begin{tabular}{|c|c|}
\hline $\begin{array}{l}\text { Maka adalah yang mewajibkan } \\
\text { kepada orang yang akil balig itu } \\
\text { bahwa mengenal apa barang yang } \\
\text { wajib dan barang yang mustahil } \\
\text { dan barang yang jaiz. Maka adalah } \\
\text { wajib Allah taala bersifat dua puluh } \\
\text { setengah } 50 \text { yang dikenal oleh } \\
\text { orang yang akil balig. }\end{array}$ & $\begin{array}{l}\text { Then it is obligatory for those who } \\
\text { have reached puberty to know that } \\
\text { what is necessary and impossible } \\
\text { and reasonable things. Then it is } \\
\text { necessary for Allah to be of the } \\
\text { twenty attributes and half of } 50 \\
\text { known by a person who has reached } \\
\text { puberty. }\end{array}$ \\
\hline
\end{tabular}

In addition to salik, the reader of books on Sufism is also commonly referred to as 'student'. This is related to the typicality of studies on Sufism which discusses something special called the esoteric dimension. Studies on Sufism provide a perspective on spirituality which is the inner dimensions of religion or the inner aspects of religion. Meanwhile, non-Sufism books discuss religious knowledge that can be understood by anyone which is called the exoteric dimension of religion. Islamic scholars discussing this exoteric dimension usually refer to the audience as muta'allim or tālib al-ilm. The fields of study include linguistics, Qur'anic studies, hadith, Jurisprudence, and other general sciences.

The articulation of the MSS AAT text which narrates the twenty attributes of Allah has a straightforward formulation and simple arguments. Indicators of the straightforwardness of the MSS AAT articulation formulation can be seen from the form of a direct comparison between the narration of what is necessary to be of His attributes, and what is impossible to be of His attributes. After mentioning what is necessary to be of His attributes, and its meaning, the formulation of MSS

${ }^{8}$ Abang Ahmad C N - M S A A T 02 Tahir, "Penjelasan Sifat Dua Puluh" (Putussibau, April 18, 1904), /2r/. 
AAT narrative text directly includes the word 'impossible' and the meaning of what is impossible to be of His attributes. For example, "Wujud (Existence) means that the Dhāt (Essence) of Allah taala exists, the opposite is it is impossible that the Dhät of Allah taala is non-existent, the argument is the whole universe." The use of the 'whole universe' argument for all the necessary and impossible attributes of Allah mentioned in the MSS AAT is an indicator of the simplicity of the argument in the articulation of the MSS AAT text narration.

\begin{tabular}{|c|c|c|}
\hline Wujud $^{9}$ & $\begin{array}{l}\text { artinya ada Dhāt 'Zat' } \\
\text { Allah taala itu } \\
\text { lawannya } \\
\text { means Dhāt 'Essence' } \\
\text { of Allah taala exists, the } \\
\text { opposite is }\end{array}$ & $\begin{array}{l}\text { mustahil tiada Zat Allah taala } \\
\text { itu dalilnya [baru] alam } \\
\text { [sekalian] } \\
\text { It is impossible for the Dhät } \\
\text { of Allah to be non-existent, } \\
\text { the argument is [then] the } \\
\text { [whole] universe }\end{array}$ \\
\hline The beginning & $\begin{array}{l}\text { artinya dahulu Zat Allah } \\
\text { taala lawannya } \\
\text { means the Dhāt of Allah } \\
\text { taala is the beginning, } \\
\text { the opposite is }\end{array}$ & $\begin{array}{l}\text { mustahil ada yang } \\
\text { mendahului Dia dalilnya baru } \\
\text { alam sekalian } \\
\text { it is impossible for anyone to } \\
\text { precede Him, the argument is } \\
\text { [then] the [whole] universe. }\end{array}$ \\
\hline$B a q \bar{a}^{\prime}$ & $\begin{array}{l}\text { artinya kekal Zat Allah } \\
\text { taala itu lawannya } \\
\text { means the Dhāt of } \\
\text { Allah Almighty is } \\
\text { eternal, the opposite is }\end{array}$ & $\begin{array}{l}\text { mustahil binasa Zat Allah } \\
\text { taala itu dalilnya baru alam } \\
\text { sekalian } \\
\text { it is impossible for the Dhāt } \\
\text { of Allah Almighty to perish, } \\
\text { the argument is [then] the } \\
\text { [whole] universe }\end{array}$ \\
\hline $\begin{array}{l}\text { Mukhālafatuhū } \\
\text { li al-ḥawādithi }\end{array}$ & $\begin{array}{l}\text { artinya bersalahan Zat } \\
\text { Allah taala itu } \\
\text { lawannya } \\
\text { means the Dhāt of } \\
\text { Allah Almighty is } \\
\text { unique, the opposite is }\end{array}$ & $\begin{array}{l}\text { mustahil bersamanya Zat } \\
\text { Allah taala itu bagi segala } \\
\text { yang baru dalilnya baru alam. } \\
\text { it is impossible for the Dhāt } \\
\text { of Allah Almighty to be similar } \\
\text { to anything, the argument is }\end{array}$ \\
\hline
\end{tabular}

9 What is meant by wujud is existence, not maujūd which questions the physical or material nature of things.. 
[then] the [whole] universe. ${ }^{10}$

The straightforward formulation and simplicity of the MS AAT 01 and MS AAT 05 arguments in articulating the narration of the twenty attributes of Allah ta'āla is part of the form of representation of the West Kalimantan Muslim Dayak identity. ${ }^{11}$ The MSS AAT text narrative about the attributes of Allah is a form of discourse that is present in the dialogue of faith between the doctrines of Islamic religious beliefs and the belief systems of the indigenous people of West Kalimantan. This Islamic dialogue with local culture took place peacefully because it resulted in confluence in various spheres of life. This is evidence of doctrinal dialogue between Kalam Al-Ash'ārī and his audience in the interior of West Kalimantan. The straightforward formulation and simplicity of the MS AAT 01 and MS AAT 05 arguments can be understood as a form of Islamic religious instruction in accordance with the characteristics of the interior community of West Kalimantan.

As followers of Islam, the people of Kapuas Hulu in the interior of West Kalimantan at the beginning of the 20th century were a society that had not been familiar with Islam. ${ }^{12}$ However, tangible indications of a presence of indigenous Muslims in Southeast Asia do not predate the late thirteenth century. ${ }^{13}$ In addition to the considerable distance and the transportation route that was difficult at that time, the spread of Islam in the interior of West Kalimantan was not as fast as that in the coastal areas which had received the arrival of Islam. Based on previous studies, the West Kalimantan coastal area that first received

10 Tahir, "Sifat Dua Puluh Semitau," /1r/.

${ }^{11}$ Faizal Amin, Manuskrip Koleksi Abang Ahmad Tahir Kapuas Hulu: Kajian Teks Dan Parateks Tentang Konstruksi Identitas Dayak Islam Pada Awal Abad Ke-20, ed. Mohammad Nor Ichwan, 1st ed. (Semarang: Rasail Media Group, 2020).

12 Mohd. Malik, Ade Unang, and Prayitno, Masuknya Islam Ke Kabupaten Kapuas Hulu (Putussibau: Departemen Agama Kabupaten Kapuas Hulu, 1985); Juniar Purba and Yusriadi, Sejarah Kerajaan Silat Di Kabupaten Kapuas Hulu (Pontianak: STAIN Pontianak Press, 2013), 27-28.

13 Carool Kersten, A History of Islam in Indonesia: Unity in Diversity (Edinburgh: Edinburgh University Press, 2017), 11; Merle Calvin Ricklefs and Husni Syawie, Sejarah Indonesia Modern 1200-2004, 3rd ed. (Jakarta: Serambi, n.d.). 
to the arrival of Islam was Sambas in the early 15th century. ${ }^{14}$ In 1407 , there was a Chinese Muslim community in Sambas known as the Hanafi Muslim group. Then in 1463, a number of Admiral Cheng Ho's men had settled and mingled with the people of Sambas. They were brought by Admiral Cheng Ho on seven Nan Nyang expeditions on the orders of Emperor Cheng Tsu or Jung Lo, who was the fourth emperor of the Ming Dynasty. 15

Meanwhile, the interior of West Kalimantan that first accepted Islam was Sintang ${ }^{16}$ based on information from the manuscript written by Prince Ratu Idris in $1241 \mathrm{H}\left(1825 / 26\right.$ AD). ${ }^{17}$ Nevertheless, they were groups of people who have adopted a belief system commonly referred to as Hinduism. They had already had religious experiences that are closely related to the mystical world, both animism and dynamism belief systems. ${ }^{18}$ Therefore, the MSS AAT text not only targets the knowledge and reasoning aspects of its audience, but also provides more discussions on the mystical aspects of Sufism. So there is a synhesis and narrative integration of the twenty attributes of God as the basis of Islamic theology with the teachings of Sufism. As a cultural expression, this synthesis and narrative integration is a mirror of the identity of Dayakness and Islam in the cognitive dimension. ${ }^{19}$

\section{B. Synthesis Theology and Sufi Doctrine}

MS AAT 01 and MS AAT 05 not only provide an explanation of the attributes of Allah and His Messenger in terms of theological doctrines, but also in terms of Sufistic doctrines. The representation of Muslim Dayak identity in the Kalam al-Ash'ārī discourse can be seen through indicators of the confluence of

${ }^{14}$ A. Rahman et al., Kabupaten Sambas: Sejarah Kesultanan Dan Pemerintah Daerah (Sambas: Dinas Pariwisata Pemda Kabupaten Sambas, 2001), 15.

15 Hermansyah, Erwin, and Rusdi Sulaiman, Islam Di Borneo: Jejak Tasawuf Dalam Naskah Muhammad As'ad Sambas, I (Pontianak: IAIN Pontianak Press, 2017), 10-11.

16 Sintang is a regency in West Kalimantan which is located $\pm 300 \mathrm{KM}$ from Pontianak, the capital of West Kalimantan Province and is $\pm 200 \mathrm{KM}$ from Putussibau, in Kapuas Hulu Regency where MSS AAT is located.

17 Hasanuddin Syahzaman, Sintang Dalam Lintasan Sejarah (Pontianak: Romeo Grafika, 2003), 30.

18 Merle Calvin Ricklefs, Mystic Synthesis in Java: A History of Islamisation from the Fourteenth to the Early Nineteenth Centuries, 1st ed. (Norwalk CT USA: EastBridge Signature Books, 2006).

19 Irwan Abdullah, Konstruksi Dan Reproduksi Kebudayaan, 3rd ed. (Yogyakarta: Pustaka Pelajar, 2009), 190-91.

JURNAL THEOLOGIA - Volume 31, No. 2, Desember 2020 
Islamic theology discourse with Islamic mysticism discourse. The moderate doctrine of Kalam al-Ash'ārī provides knowledge for a salik to understand and practice Sufism. Kalam al-Ash'ārī seems to take a salik to the ma'rifatullah gate through the path of Sufism. In this case, MS AAT 05 / 18v / mentions:

\begin{tabular}{|c|c|}
\hline $\begin{array}{l}\text { Adapun harus bagi Allah taala itu } \\
\text { satu juwa yaitu berbuat tiap-tiap } \\
\text { mungkin atau meninggalkan } \\
\text { berbuat Dia. Maka wajib bagi Allah } \\
\text { taala itu dua puluh dan mustahilnya } \\
\text { dua puluh dan harusnya satu juwa } \\
\text { jumlahnya empat puluh satu. Maka } \\
\text { masuklah semuanya di dalam } \\
\text { kalimat 'Lā ilāha illā Allāh'. }{ }^{20}\end{array}$ & $\begin{array}{l}\text { Only, capable of doing or not } \\
\text { anything He pleases. Then } \\
\text { necessary for Allah to be } \\
\text { Twenty [Attributes] and impo } \\
\text { to be of the Twenty, and there } \\
\text { be one so as to be forty or } \\
\text { everything includes in the ser } \\
\text { 'Lā ilāha illa Allāh'. }\end{array}$ \\
\hline
\end{tabular}

The narratives of MS AAT 01 and MS AAT 05 not only explain the concept of the Attributes of Allah taala in the Islamic theological doctrine of Ash'âriyah, but also invite the reader to appreciate it in the practice of Islamic religiosity. This is also related to the concept of the attributes of the Messengers of Allah ta'ala, which must also be known by a salik, which consists of nine, four of necessary, four of impossible and one attribute must be 'jais'. The concept of the attributes of the Messenger of Allah is: șiddi q which means true and its opposite is it is impossible for him to be false; amānah which means trustworthy and its opposite it is is impossible for him to betray, tabligh which means to reveal and its opposite it is impossible for him to conceal, and fațānah which means smart and its opposite is it is impossible for him to foolish. In addition, it is necessary for the Messenger to be of one attribute, i.e. behaving like a human that does not bring shortcomings to his self-respect. Although the explanation of the fifty concepts of the Attributes of Allah and His Messenger is not more than two pages, but the effort of its internalization must be made as long as one lives.

20 Tahir, “Kitab Risalah Perukunan Islam," /18v/. 


\begin{tabular}{|c|c|}
\hline $\begin{array}{l}\text { Maka adalah jumlah keduanya [sifat- } \\
\text { sifat Allah dan rasul-Nya] itu empat } \\
\text { puluh satu sama sembilan jadilah lima } \\
\text { puluh betul 'āqāid al-īmān yang } \\
\text { termasuk didalam kalimat "Lā ilāha } \\
\text { illā Allāh Muhammad rasūl Allāh." } \\
\text { Maka amalkan olehmu akan "Lā ilāha } \\
\text { illā Allāh" itu supaya mesra pada } \\
\text { tubuhmu. Supaya biasa engkau } \\
\text { menyebutnya dengan lidahmu pada } \\
\text { ketika hendak mati sekurangnya } \\
\text { seratus kali didalam satu waktu } \\
\text { sembahyang supaya mesra pada }\end{array}$ & $\begin{array}{l}\text { So the sum of both [the attributes } \\
\text { of Allah and His Messenger] is } \\
\text { forty-one plus nine equals fifty, } \\
\text { indeed 'āqāid al-īmān includes the } \\
\text { sentence "Lā ilāha illā Allāh } \\
\text { Muhammad rasūl Allāh." So } \\
\text { practice "Lā ilāha illā Allāh" to be } \\
\text { familiar to your body. So that you } \\
\text { get used to saying it with your } \\
\text { tongue when you are about to die } \\
\text { at least a hundred times in one } \\
\text { prayer time to be familiar to your } \\
\text { body physically and mentally. }\end{array}$ \\
\hline
\end{tabular}

In addition to dhikr at least a hundred times in each prayer, MSS AAT also explains how to use the word Muhammad (محمد) and Ahmad (أحمد) as a form of internalization of one's creation and the performance of his prayers. Therefore, a salik should be able to internalize that his existence is a representation of the arrangement of letters of the word Muhammad (محمد). MS AAT $01^{22}$ and MS AAT $05^{23}$ explain that if you want to use the letters Muhammad (محمد), then the head is like $\operatorname{mim}(-)$, the first, both arms like há $(ح)$ and the stomach like the second $\operatorname{mim}(-)$, the two legs like dāl ( $(-)$ )." This is the origin of human beings that should be maintained in one's consciousness so that he is safe in the afterlife.

Quoting the book, Daqāiq Akhbār,24 MS AAT 01 and MS AAT 03 mentions: (Lā yuhraqu aḥadun min al-kuffār 'alá șūratihi bal tubaddalu șūratuhū 'alá șūrati al-khinzir). It means that "an infidel is not burnt of his original appearance [as a human being] but it is replaced by the appearance of a pig." In addition to using the word Muhammad (محمد), a salik should internalize the prayer movements as a representation of the letter arrangement of the word Ahmad (أحمد). In this case,

${ }^{21}$ Tahir, /18v/.

22 Tahir, "Sifat Dua Puluh Semitau," /2r/.

${ }^{23}$ Tahir, "Kitab Risalah Perukunan Islam," /19v/.

24 Anonymous, Daqāiq Akhbār fi Dhikri al-Jannah wa-al-Nār A4 - Yunus Lungka, Ahmad bin Muhammad (Patani-Tailand: Matba'ah Halabi, n.d.).

JURNAL THEOLOGIA — Volume 31, No. 2, Desember 2020 
MS AAT $01^{25}$ dan MS AAT $05^{26}$ states that: "As for Allah Almighty, he commanded all his servants to pray in agreement with the letters of the name of Ahmad (أحمد). First, standing upright is like alif (I); and ruku' is like há ( ( ), and sujūd is like mìm ( $(-)$ and siting like dāl (د)." The conformity between the movements of prayer with the arrangement of letters from the word Ahmad (أحمد) shows that the expression of human attitudes and behaviour as a 'praiseworthy' Muhammad is an activity of 'praising' ahmad. A salik is not only required to understand the concept of the attributes of Allah and His Messenger but also has an awareness of his noble self-existence.

Furthermore, MS AAT 01 and MS AAT 05 display pictures (Figure 1) showing the relationship between Allah-Muhammad-Adam.

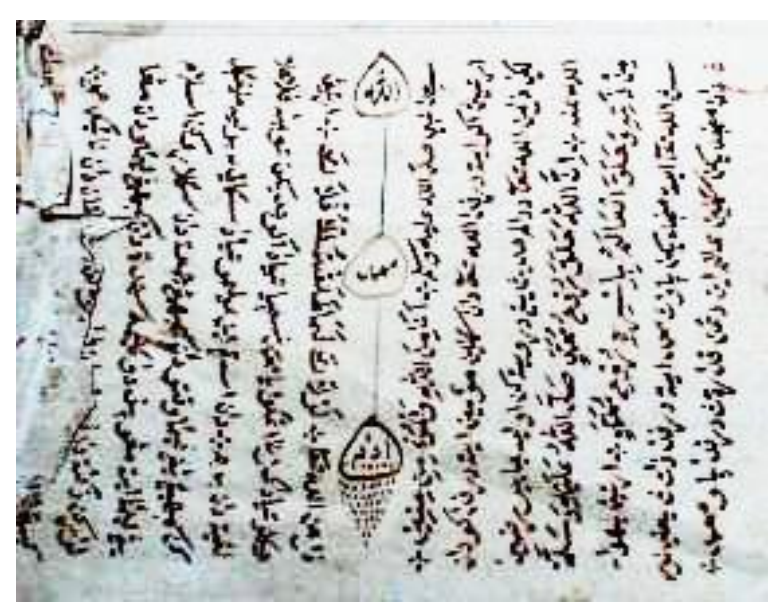

Figure 1

The relation between Allah, Muhammad, and Adam Photographed by Faizal Amin, 2 Mei 2019, Putussibau

On the right side of the vertical line it is mentioned, "Allāh ta'ālá said [in hadith qudsī] (lawlā-ka famā khalaqtu al-aflāk). It means, Were

25 Tahir, "Sifat Dua Puluh Semitau," /2r/.

26 Tahir, "Kitab Risalah Perukunan Islam," /19v/. 
it not for you, O Muhammad, I would not have created the seven heavens and the earth." And this indicates that [one should] never leave the five daily prayers and Friday prayer and all the five pillars of Islam, uttering the two sentences of shahadat and five prayers and pay zakat and fitrah and fasting in the month of Ramadan and go on pilgrimage to the House of Allah if is capable of, then this science has its benefits. While on the left side of the vertical line it is stated that the Word of the Prophet șallá Allāh 'alayhi wa-sallam (Anā min Allāh wa-al-mu'min minnī). It means that I am from Allah ta'ālá and all the believers from me and again the words of Allah ta'ālá in the hadith [qudsī) narrated by Jabir r.a. (Inna Allāh khalaqa rūḥ Muhammad șallá Allāh 'alayh wa-sallam min dhātih wa-khalaqa al-'âlam bi-ishrihi rūh Muhammad). It means that Allah ta'ālá created Muhammad from His essence that is His light and created all these worlds with His power from the scent of Muhammad.

Before returning to discussing the subject of fiqh law, the text of MS AAT 05 discusses the origin of the twenty attributes as things that refer to the afāl Allāh taala which are used as all acts commanded by Allah Taala. MS AAT 05 explains the reasons for Allah taala to be of nafsiyah, salbiyah, maani and maknawiyah. MS AAT 05 narrates its description in the form of a question and answer dialogue. Regarding the question of why Allah taala is of nafsiyyah attribute, He is One in existence. Because Allah Taala is of Nafsiyyah attribute because He shows His servants since Allah Taala's Dhāt is One and the Only One being His attribute and the Only One being His $A f \bar{a} l$ that is the reason for [Allah] Taala being of Nafsiyyah attribute. As for the question of why Allah taala is of salbiyyah attribute which is due to five matters. Because Allah Taala sent His messenger to His servants the five pillars, of which the first being shahadāt; and second, prayer; third, paying the alms; fourth, fasting; fifth, pilgrimage. And the five-time prayers are the origin of Allah Taala is of five-salbiyyah attributes. The question of why Allah taala is of ma'ānī attribute is due to seven matters. Because Allah shows all his deeds in seven (degrees of) dignity. First 'ahadiyyah; second, wāhidah, third, wāhidiyyah; fourth, 'alam rūh; fifth, 'alam mithāl; sixth, 'alam ajsam; seventh, 'alam insān. That is how Allah Taala states the seven attributes of $m a^{\prime} \bar{a} n \bar{n}$. The question of why Allah taala is of ma'nāwiyyah attribute is due to seven matters. Because Allah revealed to all greatness namely seven matters, first, the earth was created in seven layers and the sky in seven layers, that's why Allah taala is of ma'äniyyah attribute, due to these seven matters. ${ }^{27}$

27 Tahir, /19v/.

JURNAL THEOLOGIA — Volume 31, No. 2, Desember 2020 
A more detailed discussion of the categories of the Attributes of Allah is found in MS AAT 02. The text begins by explaining the concepts of kadim and muhaddath as starting points for understanding Allah's attributes.

\begin{tabular}{|c|c|}
\hline $\begin{array}{l}\text { ladim' kedua adanya muhaddath. } \\
\text { laka adalah adanya qadim itu } \\
\text { aitu adanya Dhāt 'Zat' Allah taala } \\
\text { wal tiada dengan permulaan } \\
\text { khirnya tiada dengan bersudahan } \\
\text { elamanya dan tiada dijadikan } \\
\text { ulah adanya Zat Tuhan kita yang } \\
\text { laha besar dan yang maha } \\
\text { lenang. Maka adalah adanya } \\
\text { uhadddath itu yaitu adanya } \\
\text { engan permulaan dan akkhirnya } \\
\text { engan berkesudahan dan tiada } \\
\text { oleh ada sekalian yang baharu ini } \\
\text { elainkan dengan dikehendaki }\end{array}$ & $\begin{array}{l}\text { So it } \\
\text { means } \\
\text { 'Essenc } \\
\text { beginn } \\
\text { Him, a } \\
\text { nothing } \\
\text { equival } \\
\text { the Es } \\
\text { Great a } \\
\text { is the }\end{array}$ \\
\hline
\end{tabular}

The concept of Dhät referred to in MS AAT 02 is certainly not "substance" that is material in nature such as Solids, Liquids and Gases. The Dzat is the Essence. The kadim and muhaddath discourse which discusses the state of the Dhat gives rise to the concept of jazm and 'ard. If dhat is understood in itself as a body created from nature, then jazm is a natural substance and 'ard is its attribute. Jazm itself is divided into jazam jisim and jazam jauhar.Jazam jisim is a substance that can be divided (can be shared and received), while jazam jauhar is a substance that can never be divided. Meanwhile, MS AAT 02 explains that the law of reason is divided into three parts, namely necessary, impossible and jaiz. Necessity according to the law of reason is that if something cannot be accepted by logic/reason, then the state of its non-existence is the existence.

${ }^{28}$ Tahir, “Penjelasan Sifat Dua Puluh,” /1r/. 
Impossibility is the opposite of necessity. Jaiz in MSS AAT is synonymous with dharus. According to MS AAT 02, the concept of dharus in the law of reason is something is valid of its existence and valid of its non-existence. In this context, the concept of jazam according to the law of reason is divided into three parts as well, namely necessary, impossible and jaiz. Based on this argument, MS AAT 02 states that it is obligatory for people who have reached puberty to know the fifty attributes that serve as the basis of faith in Islam.

... Therefore, it is necessary on every person who has reached puberty that he be required by shara' and that he be aware of matters which are necessary, impossible and jaiz to the rights of our God and the matters of the most glorious. So it is necessary for the person who has reached puberty to know what is necessary and what is impossible and what is jaiz. Therefore, Allah Ta'ala must be of twenty attributes and a half 50 known to people who have reached puberty.

\begin{tabular}{|c|c|}
\hline $\begin{array}{l}\text { lah taala bersifat dua } p \\
\text { tengah } 50 \text { yang dikenal }\end{array}$ & $\begin{array}{l}\text {... Th } \\
\text { every } \\
\text { puber } \\
\text { shara } \\
\text { matte } \\
\text { impos } \\
\text { our } \\
\text { most } \\
\text { for th } \\
\text { puber } \\
\text { and } u \\
\text { jaiz. }\end{array}$ \\
\hline
\end{tabular}

The text narrative of MS AAT 02 not only provides different statements to explain the attributes of necessary, impossible, and jaiz for

${ }^{29}$ Tahir, /2r/. 
Allah and His Messenger, but also gives more rational arguments in explaining the categories of its division. According to MS AAT 02, the first attribute of Allah is wujud (existence) which means that the existence of the Essence of Allah taala is impossible, for example, to be non-existent. The second attribute is qidam; meaning that the existence of the Essence of Allah Taala is not preceded by anything, impossible, for example, to be of something new. The third attribute is $b a q \bar{a}$ 'or eternal; it means that the existence of the Essence of Allah taala is related to anything, impossible to be mortal which means damaged. The fourth attribute is mukhalafatuhu li-al-hawädithi or different of all that is new; it means that the existence of the Essence of Allah taala is not similar to anything new, it is impossible, for example, to resemble anything new (Abang Ahmad C N - M S A A T 02 Tahir 1904, / 2r-2v /). So, that is how MS AAT 02 describes the attributes of Allah Taala.

An explanation of the categories of the division of the twenty attributes of Allah Taala is also explained in MS AAT 02. It is mentioned that a person who has reached puberty must also know that the twenty attributes as Allah Taala is divided into four parts or four categories, namely the attributes of nafsizah, salbīyah, ma'āni , and ma'nawìyah. The first part of the attribute of nafsiyyah namely the only one, the attributes of nafsiyah are by itself, meaning that essence of kita-kitaan. Why is it called the essence of kita-kitaan because there is no radiance of the same essence? Imam al-Ash'ârī said, the definition of the attribute of nafsiyah is hiya huwa, hiya is the attribute of huwa; there is the essence; there is that it is the essence that has an attribute of lafaz which means the essence. The second part of it is the attribute of salbiyah which is the five attributes that is ithbāt for its essence, i.e. qidām, baqā', mukhalafatuhu li-alhawādithi, qiyāmuhu bi-nafsihi, wahdāniyyah. The meaning of salbiyah is the attribute of rejecting anything that is not worthwhile that comes to the Essence of Allah Taala. It all begins the definition of the attribute of salbiyah; there is no existence of fish, it is only rumoured, Imam Shaikh al-Rāzī said "Hiya ghairuhu" meaning that the attribute is different from the essence because its names are different. The third part of the attribute of $m a^{\prime}$ anni is the seven sidat that it exists to the essence namely qudrat, iradat, ilmu, hayat, sama', bașar, kalam. Ma'āni (meaning) of the essence means the attribute must exist to the essence and the essence must be of its attribute. It all begins with the definition of the attribute of ma'ānī, it exists to dhihin and it exists to kharij; Imam Sanūsì said, "Lā hiya huwa wa-lā hiya ghairuh." It means that there is no attribute of the essence none other 
than the attribute of the essence itself. The fourth part of the maknawiyah attribute is the seven thabit attributes for the essence namely qãdirun, muridun, 'âlimun, sāmi'un, bașirun, mutakallimun. It means that maknawiyah is the meaning for others, because of ma'āni then it is maknawiyah. It all begins with the definition of the attribute of maknawiyah, it exists to dhihn which is the opinion in the heart between reinforcing something or reckoning something. As for the meaning of khärij, it is an opinion that is out of the heart such as seeing something externally or hearing something said, that is khārij. 30

\section{Al-Ash`āri Theological Features}

The theological argument mentioned in the text extract of MS AAT 02 refers to three figures, namely Imam al-Ash'ārī, Shaikh al-Rāzī, and Imam Sanūsī. MS AAT 02 also outlines various aspects of the attributes of Allah and His Messengers such as ta'alluq between attributes, the category of the istighna ${ }^{\prime}$ and iftiqār attributes, the origins of the attributes of Allah and His Messenger. Also, there is a brief description of the history of the birth of Prophet Muhammad, the pillars of faith, the pillars of Islam, etc. The construction of the argument built in the MS AAT 02 narrative text is a representation of the Aqida of the Ahlusunnah Waljamaah. This confirms the argument that Kalam al-Ash'ārī is the construction of Islamic theology in the text of MS AAT 02.

Kalam al-Ash'ārī is a doctrine of Islamic theology that was initiated by Abu Hasan al-Ash'ârī (260H-324H/873M-935M). ${ }^{31}$ He lived in the same period as Imam al-Turmudhi $(297 \mathrm{H} / 842 \mathrm{M})$ who was the last Hadith compiler. This happened on the momentum of consolidation of Sunni ideology thanks to the support of the Caliph al-Mutawakkil who discontinued the Mu'tazillah ideology as the official state ideology ${ }^{32}$. Thus, the Sunni group or Ahlussunnah waljamaah became the majority. Its influence is not only in the field of theology, but also in the field of Islamic jurisprudence, mysticism, and politics. In the field of Islamic

30 Tahir, /3v/.

${ }^{31}$ His full name was Abu al-Hasan Ali bin Isma'il bin Abi Bashar bin Ishaq bin Salim bin Ismail bin Abdillah bin Musa bin Bilal bin Abi Burdah Amir bin Abi Musa Al-Asy’ari, a companion of the Prophet s.a.w.

32 Zainun Kamal, “Kekuatan Dan Kelemahan Faham Asy’ariyah Sebagai Doktrin Aqidah," in Kontekstualisasi Doktrin Dalam Sejarah, ed. Budhy Munawar Rahman (Jakarta: Yayasan Waqaf Paramadina, 1994), 131. 
jurisprudence, it refers to the four imams of the madhhab, namely Imam Abu Hanifah, Imam Malik bin Anas, Imam Ahmad bin Hambal, and Imam Shafi'i. Meanwhile, the field of Sufism refers to Imam al-Ghazali and the field of politics refers to al-Mawardi and Ibn Taimiyah. In the field of politics, the Sunni denomination is even a factor that distinguishes it from Shi'ah denomination.

As a school of theological thought, Kalam al-Ash'ârī is an attempt to synthesize the tendencies of rationalism and fatalism. In this case, Mahmuddin 33 referred to it as the middle ground between rational and dogmatic theology. While Nasr ${ }^{34}$ argued that Abu Hasan al-Ash'ârii broadly offers a moderate position argument in almost all theological debates of his time. Al-Ash'ārī makes reasoning subject to revelation and rejected creative human free will. Al-Ash'ārī emphasizes the power of God in everything that happens behind the verses of the Qur'an. Therefore, al-Ash'ārī argues that every human being must continue to account for his deeds.

Kalam al-Ash'āri's view of God and His attributes is at the middle position in the Islamic theological discourse. Kalam al-Ash'âni is between the views of Siffatillah and Mu'tazilah groups. Similar to the Sifatiyah group, the Mujassimah (anthropomorphic) believe that the attributes of Allah must be understood literally as mentioned by the Qur'an and hadith. Meanwhile, the views of the Mu'tazillah group deny the existence of the attributes of God and state that the attributes of Allah are none other than His Essence or dhăt. In this case, Kalam alAsh'âri's view states that the attributes of Allah are unique and cannot be compared or likened to human nature. Al-Ash'ârī does not limit the attributes of God to as many as seven, but all the attributes of Allah originate from authentic naș or authoritative texts. All of these attributes are accepted without takyijf, ta'țil, tabdìl, tamthil, and tahrïif.

According to Kalam al-Ash'ârī's view, Allah has the attributes as stated in the Qur'an. Therefore, Allah knows with 'ilm, lives with hayāt, listens with samā', sees with bașar, speaks with kaläm, reigns with qudrat, intends with iradat and so on. Likewise, Allah has a face, arms, feet, calves, and so on. The attributes of

33 "Pengaruh Faham Asy'ari Pada Pemikiran Masyarakat Tradisonal," Al-Fikr: Jurnal Pemikiran Islam 21, no. 2 (2017): 75.

34 Sayyed Hosein Nasr, Intelektual Islam Teologis, Filsafat Dan Gnosis (Yogyakarta: Pustaka Pelajar dan CIIS, 2009), 13. 
Allah are azali, qadim, and exist on the dhāt of Allah. However, these attributes are not Allah's dhāt nor are they other than dhāt Allah ta'ālá. ${ }^{35}$ Kalam al-Ash'ārī states that the attributes of Allah are unique and cannot be compared or even likened to human nature. The attributes of Allah are azali, qadim, and exist on the dhāt of Allah. However, these attributes are not dhāt of Allah and nor are they other than the dhāt of Allah ta'ālá. Al-Ash'ārī does not limit the attributes of God to as many as seven, but all the attributes of Allah originate from authentic nas or authoritative texts. All of these attributes are accepted without takyîf, ta'țil, tabdīl, tamthïl, and tahrîf. This is stated in MS AAT 01 as a matter separate from qiyas existence.

\begin{tabular}{|c|c|}
\hline $\begin{array}{l}\text { Maka hendaklah diketahui olehmu } \\
\text { pertama tubuh, kedua hati, ketiga } \\
\text { nyawa, keempat rahasia. Maka } \\
\text { ketahui akan olehmu adapun mu- } \\
\text { shahadah-kan af'ál Allāh dan asmā' } \\
\text { Allāh dan șifat Allāh dan dhāt Allāh } \\
\text { yakni lepaslah daripada qiyas } \\
\text { adanya. Tamat. }{ }^{36}\end{array}$ & $\begin{array}{l}\text { So you should be aware that, first } \\
\text { the body, second the heart, third the } \\
\text { soul, fourth the secret. So you should } \\
\text { know, declare the shahada of af'āl } \\
\text { Allāh and asmā 'Allāh and the } \\
\text { Attributes of Allāh and dhāt of Allāh } \\
\text { namely [it should be] free from } \\
\text { qiyas. The End. }\end{array}$ \\
\hline
\end{tabular}

The presence of texts about the doctrine of the attributes of Allah in the MSS AAT shows that Abang Ahmad Tahir is a follower of Kalam al-Ash'ārì's thoughts. This is a logical consequence because in the Kalam thought discourse, there is a polemic between the school of Kalam al-Ash'ārI and Kalam Mu'tazillah regarding the mention of the attributes of Allah. Kalam Al-Ash'ārī, and Al-Ghazālī as well, advocates mentioning the Attributes of Allah, be it necessary, impossible jaiz. Necessary attributes of Allah taala are an affirmation of the perfection of Allah that must exist in Him. The Impossible Attributes of Allah are the opposite of His Necessary Attributes. Whereas the attribute of Jaiz of Allah Taala is the prerogative of Allah Taala to intend something or not to intend anything.

35 Ahmad Amin, Ḍuhā Al-Islām, vol. 4 (Beirut: Dar al-Fikr, 1969), 75.

36 Tahir, "Sifat Dua Puluh Semitau," /2v/. 


\section{Manuscript of Kitab Sifat Dua Puluh from West Kalimantan}

The manuscript of Kitab Sifat Dua Puluh studied in this article comes from Kapuas Hulu, West Kalimantan, Indonesia. It was one of Abang Ahmad Tahir (1860-1945) manuscript collections that are identified as MSS AAT. The manuscript collections of Abang Ahmad Tahir served as codex unicus to explore the distinction of its narrative and content among other similar texts. The texts of twenty attributes of God look like a monogenesis phenomenon that each copy of codex has a lot of unique features. Among digitised Malay manuscripts in British Library, there are three texts of twenty attributes of God. ${ }^{37}$ The texts illustrate well how this subject can be treated either very succinctly or in more detail. The first text is a manuscript from Aceh (Or. 16767) that occupies just one page in a compendium of tracts on religious subjects. The text comprises a list of the twenty attributes with one- or two-word Malay translations; thus the first attribute, wujūd, 'existence', is simply explained with the Malay word $a d a$. The second text is a composite volume from Aceh (Or. 14194). The text provides a little more information, translating each attribute and giving its opposite or inadmissible (mustahil) attribute: wujūd ada artinya ada lawannya tiada, 'wujūd means existence, and it has an opposite, non-existence'. The third text is much longer and fills the whole manuscript (Or. 13716), giving a full paragraph on each attribute and its opposite, and providing proof (dālil) from the Qur'an.

Another digitised manuscript of twenty attributes of God conducted by the Endangered Archives Programme (EAP) that provides online access to several important collections of Islamic manuscripts from Southeast Asia. The project EAP153, 'Riau Manuscripts: the gateway to the Malay intellectual world', led by Jan van der Putten and Aswandi Syahri in 2007, digitised 13 collections of manuscripts from the islands of Penyengat, Bintan and Lingga, including three copies of Sifat Dua Puluh. EAP also digitised a lithographed copy of Sifat Dua Puluh, composed by Sayyid Uthman or Uthman bin Abdullah bin Yahya (18221914) in 1884 from Batavia. Meanwhile, the British Library holds several early printed copies of different compositions on Sifat Dua Puluh subject, such as syair simpulan iman composed by Haji Muhammad Said bin Haji Sulaiman from Johor and published Singapore in 1920.

${ }^{37}$ Gallop, “The Twenty Attributes of God in Malay: Sifat Dua Puluh.” 
The manuscript of Kitab Sifat Dua Puluh from West Kalimantan studied in this article is one of the eleven manuscripts of Abang Ahmad Tahir collections. ${ }^{38}$ Based on the results of the examination, the eleven manuscripts of Abang Ahmad Tahir (MSS AAT) are written in Arabic / Jawi script, in the Malay language, made/written/copied out in Semitau and Badau in the period of 1309 AH (1891 AD) until 1350 AH (1931 AD). Based on the colophon and the similarity of the written characteristics and language style, the eleven MSS AAT texts were written by the same person, i.e.. Imam Abang Ahmad Tahir or Abang Ahmad Tahir Imam. The results of this inventory and codicological study also did not find a copy of the text which is a variant or text version of the MSS AAT. Thus, the MSS AAT is treated as a single manuscript (codex unicus) reviewed with a philological and ethnographic approach.

Table 1

List of Manuscript Collection of Abang Ahmad Tahir (MSS AAT)

\begin{tabular}{|c|c|c|c|c|}
\hline No & $\begin{array}{l}\text { Manuscript } \\
\text { Code }\end{array}$ & Title & $\begin{array}{l}\text { Year of } \\
\text { Writing }\end{array}$ & $\begin{array}{l}\text { Number } \\
\text { of Pages }\end{array}$ \\
\hline \multirow[t]{2}{*}{1} & MS AAT 01 & Sifat Dua Puluh Semitau & $1320 /$ & 12 \\
\hline & & (Twenty Attributes of Semitau) & 1902 & \\
\hline \multirow[t]{2}{*}{2} & MS AAT 02 & Penjelasan Sifat Dua Puluh & $1322 /$ & 36 \\
\hline & & (Explanation of the Twenty Attributes) & 1904 & \\
\hline \multirow[t]{3}{*}{3} & MS AAT 05 & Kitab Risalah Perukunan Islam & $1340 /$ & 52 \\
\hline & & (Book of Guidance of Islamic Pillars) & 1921 & \\
\hline & Total pages & & & 100 \\
\hline
\end{tabular}

Table 1 shows that the bundle of manuscripts in the MSS AAT collection is not a long manuscript. Its thickness also varies, ranging from two pages of text to seventy. The physical condition of MS AAT 01 is quite good. It has 12 pages combined into 1 fold (kuras) that consists of 6 sheets. MS AAT 02 is also quite thick. It has 36 pages combined into 1 fold that consists of 18 sheets. Whereas the physical condition of MSS AAT 05 has been damaged because of its fragile paper and it has holes. It

38 Amin, Manuskrip Koleksi Abang Ahmad Tahir Kapuas Hulu: Kajian Teks Dan Parateks Tentang Konstruksi Identitas Dayak Islam Pada Awal Abad Ke-20, 106-9. 
has 52 pages combined into 1 fold that consists of 27 sheets. The content of MS AAT 01 contains not only narratives of twenty attributes of God, but also some aspects of Islamic jurisprudential issues. MS AAT 02 has more detailed explanations of twenty attributes of God with some categories and argumentations related to nafsiyah attributes of God, salbīyah attributes of God, ma'ānì attributes of God, and ma'nawiyyah attributes of God. Whereas, MS AAT 05 despite focusing on Islamic jurisprudential issues related to the ritual such as worship, fasting, zakat, it has explanation on theology and Sufi Doctrine.

In addition, the text of the MSS AAT which has a Sufistic character shows Abang Ahmad Tahir's identity as one of the wandering Sufis. The argument that he was a wandering Sufi can be seen from the restriction of the audience who can access his teachings. This is evident from the information of the MS AAT 01 and MS AAT 06 colophons. In the MS AAT 01 colophon, he requested that the book that discusses the theme of the Twenty Attributes not be shown to the layman. The contents of the book the Twenty Attributes should only be accessed by those who study Sufism who is often referred to as salik or students. This prohibition was given because the book the Twenty Attributes Tahir wrote contains teachings about the Science of Haqiqa which must be kept a secret because exposing it to the public might cause someone to fall into disbelief. The following is Tahir's statement in the MS AAT 01 colophon:

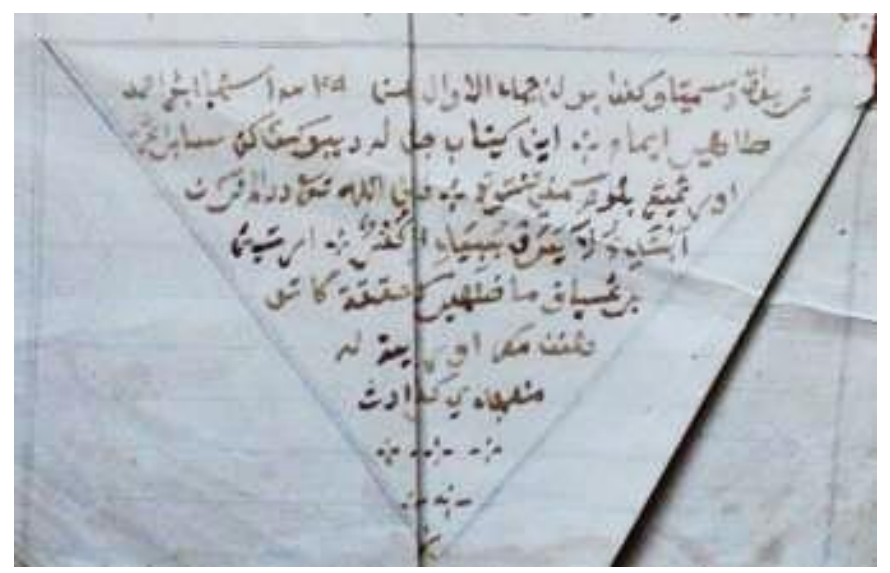

Figure 2

Colophon MS AAT 01 Page /6r/

Photographed by Faizal Amin, 2 May 2019, Putussibau 


\begin{tabular}{|c|c|}
\hline $\begin{array}{l}1907 \text { AD] saya Abang Ahmad Tahir } \\
\text { Imam. Ini kitab janganlah } \\
\text { dibukakan sembarang-sembarang } \\
\text { orang yang belum sampai tuntut. } \\
\text { [Firman] Allah taala didalam } \\
\text { Qur'an } \text { A } \text { Abtadi'u lā yarawbu } \\
\text { biyadillāh kufrun\}. Artinya barang } \\
\text { siapa men-lahir-kan hakikat } \\
\text { ketuhanan, maka orang itulah } \\
\text { menjadikafir adanya. }{ }^{39}\end{array}$ & $\begin{array}{l}\text { learning [level]. [the Word of] All } \\
\text { Almighty in the Qur'an \{Abtadi'u } \\
\text { yarawbu biyadillāh kufrun\}. Th } \\
\text { means that whoever equates t }\end{array}$ \\
\hline
\end{tabular}

\section{E. Conclusion}

The conclusion of the study on the manuscript of Kitab Sifat Dua Puluh from West Kalimantan as moderate Islamic doctrine from interior Borneo can be seen through three indicators. First, the simplicity of the narrative articulation of the attributes of Allah in MSS AAT and their arguments are indicators of the adaptation of Islamic theological doctrine with local genius tradition. MS AAT 01 and MS AAT 03 show the simplicity of narrative articulation and argumentation in explaining the attributes of Allah and His Messenger. MS AAT 01 and MS AAT 03 do not present a discussion and academic debate about the relationship between Allah ta'âla and His attributes from the perspective of the mu'atilah that denies His attributes and the perspective of the Mushābihah that equates His attributes with beings. Therefore, there are no quotations and interpretations about verses or hadith that are related to the discourse of the attributes of Allah. MS AAT 01 and MS AAT 03 also do not explain their position and argument in the discourse of the attributes of Allah in the Qur'an and Hadith. The absence of discursive narratives in MS AAT 01 and MS AAT 03 also appears in the essential description of the attributes of Allah ta'alá written in the form of doctrinal narratives for salik or students of Sufism.

39 Tahir, "Sifat Dua Puluh Semitau," 6r.

JURNAL THEOLOGIA — Volume 31, No. 2, Desember 2020 
Second, the synthesis of theology and Sufi Doctrine in the manuscript of Kitab Sifat Dua Puluh appear in between narratives of the twenty attributes of God as the basis of Islamic theology and Sufi Doctrine. As a cultural expression. This narrative integration is a mirror of the identity of Dayakness and Islam in the cognitive dimension. This reflects the mastery of the knowledge system and the perspective of the group or ideas about Islam and feasibility that apply and can be distinguished from the others. MS AAT 01 also emphasizes the unity of the concept of monotheism in the shahada doctrine. The sentence La iläha illa Allāhu Muhammad Rasūlullāh is elaborated into fifty rules which form the basis of Islamic aqida. The fifty rules are divided into two parts, namely the attributes of Allah and the attributes of the Messenger of Allah. The attributes of Allah consist of forty-one, i.e. twenty necessary attributes, twenty impossible attributes and one jaiz attribute. While the attributes of the Messenger of Allah are divided into nine parts, i.e. four necessary attributes, four impossible attributes and one jaiz attribute. Thus overall fifty basic rules must be observed by a Muslim in the creed of shahada he declares.

Third, besides displaying simple narrative articulation and argumentation, MS AAT 01 and MS AAT 05 also show a variety of phrases that are friendly and straightforward so that they display expressions of diversity that are moderate and tolerant. The simplicity of the narrative articulation and argumentation of MS AAT 01 does not contain hate speech against different belief systems in the indigenous offspring of West Kalimantan. No text narratives were found in MS AAT 01 and MS AAT 03 which bully the indigenous people of West Kalimantan and/or its belief system, either by offending, comparing, or blaming their existence. This is the most familiar characteristic of al-Ash'āri Kalam features integrated with the text of manuscript of Kitab Sifat Dua Puluh from West Kalimantan. As texts received by the people from interior Borneo of West Kalimantan, the manuscript of Kitab Sifat Dua Puluh has represented moderate Sunni's conception of Islamic theology and Sufi Doctrine. 


\section{BIBLIOGRAPHY}

Abdullah, Irwan. Konstruksi Dan Reproduksi Kebudayaan. 3rd ed. Yogyakarta: Pustaka Pelajar, 2009.

Adams, Charles J. "Forward." edited by Richard C. Martin. USA: The Arizona Board of Regents, 1985.

Amin, Ahmad. Duhạa Al-Islām. Vol. 4. Beirut: Dar al-Fikr, 1969.

Amin, Faizal. Manuskrip Koleksi Abang Ahmad Tahir Kapuas Hulu: Kajian Teks Dan Parateks Tentang Konstruksi Identitas Dayak Islam Pada Awal Abad Ke-20. Edited by Mohammad Nor Ichwan. 1st ed. Semarang: Rasail Media Group, 2020.

Anonymous. Daqāiq Akhbār fi Dhikri al-Jannah wa-al-Nār A4 - Yunus Lungka, Ahmad bin Muhammad. Patani-Tailand: Matba'ah Halabi, n.d.

Feener, R Michael. "South-East Asian Localisations of Islam and Participation within a Global Umma, c. 1500-1800." In The New Cambridge History of Islam, edited by Morgan. David 0 and Anthony Reid, Online., 470-503. Cambridge: Cambridge University Press, 2015. https://doi.org/http://dx.doi.org/10.1017/ CHOL9780521850315.

Gallop, Annabel Teh. "The Twenty Attributes of God in Malay: Sifat Dua Puluh." The British Library: Asian and African studies blog, 2015. https://blogs.bl.uk/asian-and-african/2015/12/the-twentyattributes-of-god-in-malay-sifat-dua-puluh.html.

Gallop, Annabel Teh, Wan Ali Wan Mamat, Ali Akbar, Vladimir Braginsky, Ampuan $\mathrm{Hj}$ Brahim bin A H Tengah, Ian Caldwell, Henri ChambertLoir, et al. "A Jawi Source Book for The Study of Malay Paleography and Orthography." Indonesia and the Malay World 43, no. 125 (2015): 13-171. https://doi.org/10.1080/ 13639811.2015. 1008253.

Hermansyah, Erwin, and Rusdi Sulaiman. Islam Di Borneo: Jejak Tasawuf Dalam Naskah Muhammad As'ad Sambas. I. Pontianak: IAIN Pontianak Press, 2017.

Hodgson, Marshall G S. The Venture of Islam. Chicago: University of Chicago Press, 1974.

Kamal, Zainun. “Kekuatan Dan Kelemahan Faham Asy'ariyah Sebagai 
Doktrin Aqidah." In Kontekstualisasi Doktrin Dalam Sejarah, edited by Budhy Munawar Rahman. Jakarta: Yayasan Waqaf Paramadina, 1994.

Kersten, Carool. A History of Islam in Indonesia: Unity in Diversity. Edinburgh: Edinburgh University Press, 2017.

Mahmuddin. "Pengaruh Faham Asy'ari Pada Pemikiran Masyarakat Tradisonal." Al-Fikr: Jurnal Pemikiran Islam 21, no. 2 (2017): 6976.

Malik, Mohd., Ade Unang, and Prayitno. Masuknya Islam Ke Kabupaten Kapuas Hulu. Putussibau: Departemen Agama Kabupaten Kapuas Hulu, 1985.

Mujiburrahman. "Islamic Theological Texts and Contexts in Banjarese Society: An Overview of the Existing Studies." Southeast Asian Studies 3, no. 3 (2014).

Nasr, Sayyed Hosein. Intelektual Islam Teologis, Filsafat Dan Gnosis. Yogyakarta: Pustaka Pelajar dan CIIS, 2009.

Purba, Juniar, and Yusriadi. Sejarah Kerajaan Silat Di Kabupaten Kapuas Hulu. Pontianak: STAIN Pontianak Press, 2013.

Rahman, A., Y. Ahmad, R. F. Anom, Muhadi, and Fahadi. Kabupaten Sambas: Sejarah Kesultanan Dan Pemerintah Daerah. Sambas: Dinas Pariwisata Pemda Kabupaten Sambas, 2001.

Ricklefs, Merle Calvin. Mystic Synthesis in Java: A History of Islamisation from the Fourteenth to the Early Nineteenth Centuries. 1st ed. Norwalk CT USA: EastBridge Signature Books, 2006.

Ricklefs, Merle Calvin, and Husni Syawie. Sejarah Indonesia Modern 1200-2004. 3rd ed. Jakarta: Serambi, n.d.

Syahzaman, Hasanuddin. Sintang Dalam Lintasan Sejarah. Pontianak: Romeo Grafika, 2003.

Tahir, Abang Ahmad C N - M S A A T 01. "Sifat Dua Puluh Semitau." Putussibau, April 18, 1902.

Tahir, Abang Ahmad C N - M S A A T 02. "Penjelasan Sifat Dua Puluh.” Putussibau, April 18, 1904.

Tahir, Abang Ahmad C N - M S A A T 05. "Kitab Risalah Perukunan Islam.” Putussibau, April 18, 1921. 